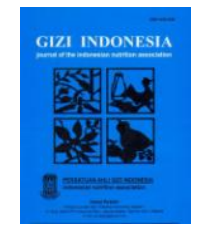

\title{
HUBUNGAN PERUBAHAN STANDAR PORSI MAKAN DENGAN SISA MAKANAN PASIEN RUMAH SAKIT HOLISTIK TAHUN 2016 \\ (STUDI SISA NASI PADA MENU MAKAN SIANG DIET DI RS HOLISTIK)
}

\section{The Relationship of The Changing in Standard Portion Toward Food Waste among Holistic Hospital Patients in 2016 (Food Waste Study of Rice on Lunch Menu in Holistic Hospital)}

\author{
Fatkhurohman ${ }^{1}$, Yanesti Nuravianda Lestari ${ }^{1}$, Dian Titis Torina ${ }^{2}$ \\ 1Program Studi IImu Gizi, Sekolah Tinggi IImu Kesehatan Holistik Purwakarta \\ 2 Instalasi Nutrisi Rumah Sakit Holistic Purwakarta \\ E-mail: yanestinur.al@gmail.com
}

\begin{abstract}
The high food waste in a hospital showed the quality of food service was not optimal. The Holistic Hospital of Purwakarta that used small, medium, and lage portion standards in its food service faced some problems regarding high food waste. This study aimed to find out the effect of meal's portion standard changes on the food waste in Holistic Hospital patients. Pre-experimental study using one group pre-post test design was done on 29 patients using convenient sampling technique.The changing of meal's portion was done for rice from medium portion $(150 \mathrm{~g})$ to small $(0.5$ or 0.25 portion). Measurement of food waste used weighing method. Data analysis used Wilcoxon test continued with Kendall-Tau correlation test. The results showed that 65.5 percent of patients were aged around 42-68 years old receiving positive diet and 34.5 percent were non-positive diets. At the beginning of diet, the food waste of rice of all patients was high (27.4-64.9\% waste of rice) and it was significantly decreased after small portion was given, even though there were still 27.6 percent of patients with $>20$ percent waste of rice. There was a significant influence between the change in diet portion of patients toward food waste of rice $(r=0.804 ; p<0.05)$. It was concluded that the changes in diet portion of patients were able to reduce the food waste.
\end{abstract}

Keywords: portion standard, plate waste

\section{ABSTRAK}

Tingginya sisa makanan pasien di Rumah Sakit menunjukkan kualitas penyelenggaraan makanan yang belum optimal. Rumah Sakit Holistic Purwakarta yang menggunakan standar porsi small, medium, dan large dalam penyelenggaraan makanan masih mengalami kendala berupa tingginya sisa makanan pasien. Penelitian ini bertujuan untuk mengetahui pengaruh perubahan standar porsi terhadap sisa makanan pasien di Rumah Sakit Holistic Purwakarta. Penelitian pre-eksperimen dengan one group pre-post test design ini dilakukan pada 29 orang pasien dengan teknik convenient sampling. Perubahan porsi makanan dilakukan pada nasi putih dari porsi medium ( $150 \mathrm{~g}$ ) menjadi small $(0,5$ porsi atau 0,25 porsi). Pengukuran sisa makanan menggunakan metode penimbangan. Analisis data menggunakan uji Chi-Square dan uji Wilcoxon yang dilanjutkan uji korelasi Kendall-Tau. Hasil penelitian menunjukkan bahwa sebanyak 65,5 persen pasien berusia 42-68 tahun menerima diet positif dan 34,5 persen menerima diet non-positif. Sisa porsi nasi di awal pemberian diet pada seluruh pasien masih tinggi (27,4-64,9\% sisa nasi) dan menurun secara signifikan setelah porsi nasi diberikan dalam porsi small $(p<0,05)$ meskipun masih terdapat 27,6 persen pasien dengan sisa nasi $>20$ persen. Terdapat pengaruh yang signifikan antara perubahan porsi diet pasien terhadap sisa nasi $(r=0,804 ; p<0,05)$. Dapat disimpulkan bahwa perubahan porsi nasi pada diet pasien mampu menurunkan sisa makanan.

Kata kunci: standar porsi, sisa makanan 


\section{PENDAHULUAN}

$\mathrm{P}$ elayanan gizi di rumah sakit (PGRS) adalah pelayanan yang diberikan rumah sakit (RS) kepada pasien yang disesuaikan dengan keadaan klinis, status gizi dan kondisi metabolisme tubuh pasien. PGRS diberikan untuk memperbaiki dan meningkatkan gizi, makanan dan dietetik masyarakat, kelompok dan individu, yang merupakan serangkaian kegiatan meliputi pengumpulan, pengolahan, analisis, simpulan, saran, penerapan dan evaluasi gizi, makanan dan dietetik demi tercapainya status kesehatan yang optimal. $^{1}$

Penyediaan atau pemberian makanan adalah satu hal penting dalam perbaikan dan peningkatan status gizi pasien di RS untuk menunjang penyembuhan penyakit. ${ }^{2}$ Pemberian makanan pasien di RS bukanlah hal yang sederhana sebab pasien secara tidak langsung dipaksa untuk memisahkan diri dari kebiasaan makan sehari-hari akibat kondisi sakit yang diderita. Jenis menu, jumlah makanan yang dikonsumsi serta jadwal makan yang disesuaikan dengan kondisi penyakit tentunya akan berdampak pada daya terima pasien terhadap makanan yang disajikan di RS. Daya terima pasien terhadap makanan merupakan faktor utama terpenuhinya asupan zat gizi pasien. Makin baik daya terima pasien, asupan zat gizi pasien akan semakin meningkat sehingga akan menunjang proses penyembuhan penyakit. ${ }^{3}$ Penelitian tahun 2013 di Rumah Sakit Umum Daerah (RSUD) Sunan Kalijaga, Kabupaten Demak, yang mengkaji hubungan tingkat kepuasan pelayanan dan konsumsi makanan dengan perubahan status gizi pasien menunjukkan bahwa makin tinggi tingkat kepuasan pelayanan makanan (rasa makanan, suhu makanan, tingkat kematangan, penampilan makanan, kebersihan peralatan, penilaian petugas penyaji dan ketepatan pemberian makanan) di RS, semakin tinggi asupan energi dan protein sehingga makin kecil terjadinya penurunan status gizi pasien. ${ }^{4}$

Penilaian ukuran sisa makanan dalam piring merupakan salah satu metode yang dapat digunakan untuk mengevaluasi daya terima pasien terhadap makanan yang disajikan. Sisa makanan dalam piring merupakan volume atau berat makanan yang dihidangkan yang tidak habis dimakan atau dibuang oleh pasien, disajikan dalam bentuk persentase. ${ }^{5}$ Hasil penelitian yang mengkaji tentang sisa makanan dalam satu siklus menu di RSUD Salatiga menunjukkan bahwa sisa makanan yang paling tinggi terdapat pada waktu makan pagi untuk jenis hidangan sayuran sebesar 48 persen dan bubur 46 persen. ${ }^{6}$ Penelitian lain tentang sisa makanan pasien yang dilakukan di Rumah Sakit Umum Pusat (RSUP) Dr. Kariadi Semarang, menggunakan metode Comstock, juga menunjukkan bahwa berturut-turut sebanyak 18, 9, dan 3 persen responden masih menyisakan hidangan sayuran, lauk hewani dan lauk nabati sebesar $>75$ persen. ${ }^{7}$ Penelitian yang dilakukan tahun 2013 pada pasien rawat inap di beberapa fasilitas kesehatan (RS umum, RS pemerintah, dan RS ibu dan anak) menunjukkan hasil bahwa pasta, nasi dan menu sayuran termasuk kategori makanan yang kurang diminati sehingga kurang dapat diterima oleh pasien rawat inap. ${ }^{8}$ Adapun screening yang telah dilakukan di RS Holistic Purwakarta, tanggal 7 Mei 2016, pada menu makan siang pasien rawat inap untuk jenis hidangan nasi dengan porsi sedang (porsi awal ketika pasien baru masuk rumah sakit), terdapat pasien yang menyisakan nasi sebesar 33,3 dan 20,6 persen yang masih belum mencapai standar maksimal sisa makanan pasien dikatakan baik (<20\%).

$\begin{array}{rrrr}\text { Rumah } & \text { Sakit } & \text { Holistic } & \text { Purwakarta } \\ \text { merupakan } & \text { rumah } & \text { sakit } & \text { berkonsep }\end{array}$ penyelenggaraan makanan yang berbeda dengan rumah sakit lain, yakni dengan menerapkan penggunaan standar porsi "kecil (small), sedang (medium), dan besar (large)" untuk menu makan pasien. Porsi sedang merupakan porsi normal yang diberikan saat pertama kali pasien dirawat di rumah sakit dan kemudian akan mengalami perubahan standar porsi menyesuaikan dengan kondisi setiap pasien. Porsi besar setara dengan 1,5 kali lipat porsi normal/sedang, sedangkan porsi kecil setara dengan 0,5 atau 0,25 kali lipat porsi normal/sedang. Perubahan porsi hanya dilakukan untuk jenis hidangan nasi. Standar ini diaplikasikan dengan asumsi dapat mempermudah pemorsian sesuai dengan diet yang diresepkan dan juga kondisi pasien. Oleh karena itu, penelitian ini bertujuan untuk mengidentifikasi gambaran perubahan porsi makan dan sisa makanan pasien serta menganalisis pengaruh perubahan standar porsi "kecil, sedang, dan besar" terhadap sisa 
makanan pasien di Rumah Sakit Holistic Purwakarta.

\section{METODE PENELITIAN}

\section{Jenis Penelitian}

Penelitian ini bersifat pre-experimental dengan one group pre-post test design yang dilakukan pada pasien di Rumah Sakit Holistic, Purwakarta. Pada penelitian ini, perlakuan yang diberikan berupa perubahan porsi makan untuk jenis hidangan nasi putih pada diet pasien, kemudian dinilai pengaruhnya terhadap sisa makanan yang dilakukan pada pengujian kedua (post test).

\section{Subjek Penelitian}

Subyek penelitian ini adalah pasien rawat inap di RS Holistic Purwakarta yang memenuhi kriteria inklusi antara lain pasien rawat inap dewasa yang berumur 18-69 tahun; dapat berkomunikasi dengan baik dan tenang; menerima diet biasa atau diet lunak; dan bersedia menjadi responden. Kriteria eksklusi antara lain pasien menjalani puasa atau mendapatkan diet tanpa nasi atau bubur. Subyek penelitian diambil menggunakan teknik convenient sampling method sejumlah 29 orang.., 10

\section{Perubahan Standar Porsi}

Perubahan standar porsi dilakukan untuk jenis hidangan nasi putih dari porsi awal sedang (150 g) menjadi porsi kecil $(0,5$ porsi atau 0,25 porsi sedang). Lauk yang disajikan pada menu awal dan setelah perubahan porsi adalah tetap atau merupakan lauk dari kelompok bahan makanan yang sejenis. Porsi makan, baik porsi makan awal maupun yang telah dilakukan perubahan, terlebih dahulu ditimbang menggunakan timbangan digital.

\section{Pengukuran Sisa Makanan}

Sisa makanan hanya dihitung untuk makanan pokok saja, yaitu nasi putih. Sisa makanan dihitung pada porsi makan awal dan porsi makan akhir (setelah mengalami perubahan porsi) untuk menu makan siang. Sisa makanan dihitung menggunakan metode penimbangan (food weighing). Sisa makanan dihitung dengan menggunakan rumus sebagai berikut: ${ }^{11}$

\section{\% Sisa Makanan = Berat Sisa Makanan $/$ Berat Awal Makanan x 100\%}

\section{Analisis Data}

Data hasil penelitian dianalisis menggunakan SPSS 16.0 for windows. Data umur, jenis kelamin, jenis diet, gambaran perubahan standar porsi dan sisa makanan subyek penelitian dianalisis secara deskriptif dan disajikan dalam bentuk tabel. Data persentase sisa makanan pasien berdasarkan umur, jenis kelamin, dan jenis diet dianalisis menggunakan uji Chi-Square. Data perubahan sisa makanan pasien dianalisis menggunakan uji Wilcoxon (Wilcoxon Signed Rank Test) dengan tingkat kepercayaan 95\% $(\alpha=0,05)$. Data pengaruh perubahan porsi makan terhadap sisa makanan pasien dianalisis menggunakan uji korelasi Kendall-Tau. ${ }^{12}$

\section{HASIL}

\section{Karakteristik Subyek Penelitian}

Hasil penelitian menunjukkan bahwa pasien Rumah Sakit Holistic, Purwakarta, yang bersedia menjadi subyek penelitian berusia antara 23-69 tahun. Sebagian besar subyek penelitian adalah perempuan (69\%) dan menerima diet positif (positive diet) selama menjalani rawat inap $(65,5 \%)$. Hasil analisis menggunakan uji Chi-Square memperlihatkan bahwa usia, jenis kelamin dan jenis diet tidak menunjukkan hubungan yang signifikan dengan persentase sisa makanan pasien (nasi putih), ditunjukkan dengan nilai $p>0,05$. Karakteristik subyek penelitian secara lengkap disajikan dalam Tabel 1.

\section{Hubungan Perubahan Standar Porsi dengan Sisa Makanan}

Hasil analisis menunjukkan bahwa penurunan porsi nasi menjadi porsi kecil dapat menurunkan persentase sisa makanan secara signifikan yang ditunjukkan dengan nilai $p<$ $0,05(p=0,0001)$. Hal ini dikaitkan dengan adanya penurunan porsi makan yang signifikan, yaitu dari porsi awal sebanyak 150 gram menjadi 0,5 , bahkan 0,25 porsi awal. 
Tabel 1

Karakteristik Subjek Penelitian berdasarkan Usia, Jenis Kelamin, dan Jenis Diet

\begin{tabular}{|c|c|c|c|c|c|c|c|}
\hline \multirow{3}{*}{ Karakteristik } & \multicolumn{4}{|c|}{ Sisa Nasi Putiha } & \multirow{2}{*}{\multicolumn{2}{|c|}{ Jumlah }} & \multirow{3}{*}{ Nilai $p^{b}$} \\
\hline & \multicolumn{2}{|c|}{ Sedikit $(\leq 20 \%)$} & \multicolumn{2}{|c|}{ Banyak (>20\%) } & & & \\
\hline & $n$ & $\%$ & $\mathrm{n}$ & $\%$ & $\mathrm{n}$ & $\%$ & \\
\hline \multicolumn{8}{|c|}{ Usia (58,0 $\pm 13,16$ tahun) } \\
\hline a. $<58$ tahun & 8 & 27,6 & 6 & 20,7 & 14 & 48,3 & 0,075 \\
\hline b. $\geq 58$ tahun & 13 & 44,8 & 2 & 6,9 & 15 & 51,7 & \\
\hline \multicolumn{8}{|l|}{ Jenis Kelamin } \\
\hline a. Laki-laki & 5 & 17,2 & 4 & 13,8 & 9 & 31,0 & 0,173 \\
\hline b. Perempuan & 16 & 55,2 & 4 & 13,8 & 20 & 69,0 & \\
\hline \multicolumn{8}{|l|}{ Jenis Diet } \\
\hline a. Positive Diet & 15 & 51,7 & 4 & 13,8 & 19 & 65,5 & 0,278 \\
\hline b. Non-Positive Diet & 5 & 20,6 & 4 & 13,8 & 10 & 34,4 & \\
\hline
\end{tabular}

Keterangan:

Yang termasuk dalam non-positive diet: diet ginjal, Diabetes Mellitus (DM), dan kanker

aSisa nasi putih pada menu makan siang setelah dilakukan perubahan diet dari porsi sedang menjadi porsi kecil

bUji asosiasi menggunakan Chi-Square, siginfikan pada level 0,05

Tabel 2. Hubungan Perubahan Porsi Nasi Putih pada Menu Makan Siang dengan Sisa Makanan Subjek Penelitian

\begin{tabular}{|c|c|c|c|}
\hline Variabel & Mean \pm SD & Min & Maks \\
\hline $\begin{array}{l}\text { Perubahan Standar Porsi (gram) } \\
\text { a. Awal } \\
\text { b. Akhir }\end{array}$ & $\begin{array}{l}150,0 \pm 0,00 \\
68,1 \pm 11,37\end{array}$ & $\begin{array}{c}150,0 \\
50,0\end{array}$ & $\begin{array}{c}150,0 \\
75,0 \\
\end{array}$ \\
\hline $\begin{array}{l}\text { Sisa Makanan }(\%)^{a} \\
\text { a. Awal } \\
\text { b. Akhir }\end{array}$ & $\begin{array}{c}46,2 \pm 18,72 \\
9,7 \pm 12,92\end{array}$ & $\begin{array}{c}20,0 \\
0\end{array}$ & $\begin{array}{l}88,7 \\
40,0\end{array}$ \\
\hline Selisih perubahan porsi makan awal dan akhir $\left(\Delta_{1}\right)^{b}$ & $81,9 \pm 11,37$ & 75,0 & 100,0 \\
\hline Selisih sisa makanan sebelum dan sesudah perubahan porsi $\left(\Delta_{2}\right)^{b}$ & $63,1 \pm 28,89$ & 17,0 & 133,0 \\
\hline
\end{tabular}

Hasil analisis korelasi menggunakan uji Kendall Tau menunjukkan bahwa terdapat korelasi yang signifikan antara perubahan porsi makanan terhadap sisa makanan di RS Holistic Purwakarta, ditunjukkan dengan nilai $p<0,05$ $(p=0,0001)$ dan nilai koefisien korelasi $(r)=$ 0,804 . Nilai $r$ tersebut menunjukkan adanya hubungan yang sangat kuat dan positif antara perubahan standar porsi dengan sisa makanan. Secara lengkap hasil analisis disajikan dalam Tabel 2.

\section{BAHASAN}

\section{Karakteristik Subyek Penelitian}

Hasil penelitian ini menunjukkan bahwa usia, jenis kelamin dan jenis diet tidak berhubungan dengan sisa makanan (nasi putih) subyek penelitian, meskipun porsi yang disajikan sudah mengalami reduksi dari porsi diet awal. Sebagian besar subyek penelitian yang berada pada rentang usia dewasa akhir hingga usia lanjut cenderung menyisakan lebih sedikit nasi dibandingkan subyek penelitian yang berusia lebih muda, meskipun secara statistik perbedaan yang dihasilkan tidak signifikan. Hal ini sejalan dengan hasil penelitian pada tahun 2005 di Rumah Sakit dr. Sardjito, Yogyakarta, yang menunjukkan bahwa tidak terdapat perbedaan sisa makanan berdasarkan kelompok umur subyek penelitian (17-60 tahun). ${ }^{13}$

Diketahui pula bahwa jenis kelamin yang berbeda tidak berkaitan dengan sisa makanan, 
meskipun sebagian besar subyek penelitian yang berjenis kelamin perempuan lebih sedikit menyisakan nasi putih dibandingkan dengan subyek penelitian laki-laki. Hasil penelitian ini bertentangan dengan penelitian sebelumnya pada tahun 2005 yang dilakukan di Rumah Sakit pemerintah di Malaysia, yang menunjukkan bahwa pasien perempuan secara signifkan menyisakan makanan lebih banyak dibandingkan pasien laki-laki. ${ }^{14}$ Penelitian lainnya pada tahun 2015 di RSUP Sanglah, Denpasar, Bali, juga menunjukkan hasil penelitian yang berbeda dengan penelitian ini, yang menyatakan bahwa terdapat perbedaan sisa makanan yang signifikan berdasarkan jenis kelamin, kelompok umur, kelas rawat dan lama rawat $(p<0,05){ }^{15}$

Jenis diet yang diterapkan di Rumah Sakit Holistic, Purwakarta, disesuaikan dengan tingkat keparahan penyakit yang diderita pasien. Diet positif pada umumnya diberikan untuk pasien rawat inap dengan kasus infeksi dan kasus degeneratif yang tidak terlalu berat. Sebaliknya, diet non-positif biasa diberikan kepada pasien rawat inap dengan kasus yang spesifik (dalam penelitian ini meliputi penyakit ginjal, diabetes mellitus, dan kanker). Pembatasan variasi makanan dalam diet nonpositif lebih ketat dibandingkan dengan diet positif, menyesuaikan kondisi penyakit pasien yang membutuhkan persyaratan diet yang lebih spesifik. Hasil penelitian menyatakan bahwa sisa nasi putih pada subyek penelitian yang mendapatkan diet positif dan non-positif tidak berbeda secara signifikan, meskipun lebih banyak subyek yang menerima diet positif yang menyisakan nasi putih dalam jumlah yang lebih sedikit dibandingkan subyek yang menerima diet non-positif. Hal ini dapat pula diartikan bahwa sebagian besar subyek dengan penyakit ringan cenderung menyisakan nasi putih lebih sedikit dibandingkan subyek dengan penyakit yang berat, meskipun secara statistik tidak menunjukkan perbedaan yang signifikan. Hasil penelitian ini dapat dikaitkan dengan penelitian sebelumnya di Rumah Sakit Umum Daerah Sleman, Yogyakarta, yang mengkaji sisa makanan berdasarkan status hipertensi, status komplikasi penyakit, bentuk makanan, dan selera makan pasien. Pada penelitian tersebut diperoleh hasil bahwa hanya selera makan yang berpengaruh secara signifikan terhadap sisa makanan pasien hipertensi. ${ }^{16}$

\section{Hubungan Perubahan Standar Porsi dengan Sisa Makanan}

Hasil penelitian ini menunjukkan bahwa penurunan porsi dapat menurunkan persentase sisa makanan pasien. Sejalan dengan penelitian yang dilakukan pada tahun 2010, pada pengunjung kantin "all you can eat" yang menyatakan bahwa penurunan porsi makanan akan menurunkan jumlah konsumsi dan sisa makanan $\quad(p<0,05)$. Porsi makanan menunjukkan hubungan positif dengan jumlah konsumsi dan sisa makanan $(r=0,897$ dan $r=0,852) .{ }^{17}$ Hal ini dapat dikaitkan dengan kondisi patologis pasien yang tidak memungkinkan untuk mengonsumsi makanan, terutama nasi putih dalam jumlah yang terlalu banyak. Subjek dalam penelitian ini merupakan pasien penyakit degeneratif kronis dan rata-rata dalam keadaan yang buruk ketika datang ke rumah sakit. Kondisi tersebut yang kemudian diduga mempengaruhi pandangan subjek penelitian terhadap penyakit yang diderita, kemungkinan kesembuhan, dan preferensi terhadap makanan. Hasil penelitian ini didukung oleh hasil penelitian pada tahun 2005 di Rumah Sakit dr. Sardjito, Yogyakarta, yang menunjukkan bahwa jenis dan keparahan penyakit dapat mempengaruhi sisa makanan pasien. Pasien luka bakar dan kanker menghabiskan lebih sedikit nasi dan sayur dibandingkan dengan pasien yang lainnya (penyakit saraf, ginjal, dan pasien pasca persalinan). ${ }^{13}$

Pasien yang menjalani rawat inap di rumah sakit dipaksa untuk keluar dari kebiasaan makan sehari-hari dan harus mengonsumsi diet tertentu yang telah disesuaikan dengan kondisi penyakit yang diderita, namun belum tentu sesuai dengan keinginan dan kebiasaan pasien. Selain itu, kondisi patologis yang diderita pasien tentunya akan mempengaruhi pandangan pasien terhadap penyakit yang diderita, pasien lebih takut untuk mengonsumsi makanan tertentu atau bahkan sebaliknya. Hal ini dapat berdampak secara langsung terhadap nafsu makan dan tingkat asupan pasien selama menjalani rawat inap di rumah sakit. Kondisi patologis sering kali dapat mempengaruhi nafsu makan dan indera perasa atau penciuman. ${ }^{16}$ Penurunan aktivitas selama di rumah sakit, konsumsi obat-obatan dan terapi lainnya yang dapat menyebabkan anoreksia, mual muntah atau gangguan saluran pencernaan dapat pula 
mempengaruhi keinginan pasien untuk mengonsumsi makanan. ${ }^{18}$ Penelitian di bidang psikologi yang mengkaji tentang kesadaran seseorang dalam mengenali faktor-faktor yang berpengaruh terhadap asupan makanan yang dilaksanakan tahun 2008 pada mahasiswa menyatakan bahwa faktor determinan utama yang berpengaruh terhadap asupan makanan terdiri dari beberapa kategori antara lain sinyal internal (lapar dan kenyang), faktor makanan (rasa, pilihan menu yang monoton/tidak berubah, kenampakan/aroma makanan, dan "mood" terhadap makanan), faktor waktu (jarak antara waktu makan), kondisi medis, dan pengaruh dari perilaku orang lain di sekitarnya. ${ }^{19}$ Penelitian lain pada tahun 2015 pada pasien di 18 rumah sakit di Kanada juga menyatakan bahwa pasien yang menjalani rawat inap di rumah sakit memiliki "barrier" terhadap makanan atau diet yang diberikan selama masa perawatan. Faktor penghambat tersebut meliputi tidak diberikan makan ketika melewati jam makan $(69,2 \%)$, hilangnya nafsu makan $(63,9 \%)$, pesanan makanan yang tidak dikehendaki (58\%), kondisi psikologis "merasa sangat sakit" $(42,7 \%)$ atau terlalu lelah $(41,1 \%)$ untuk makan, dan adanya gangguan saat makan $(41,8 \%) .{ }^{20}$ Penelitian lainnya di beberapa rumah sakit di DKI Jakarta tahun 2011, yang mengevaluasi sistem penyelenggaraan makanan lunak dan menganalisis sisa makanan lunak yang menyatakan bahwa sebagian besar responden tidak menghabiskan makanan karena porsi diet yang disajikan terlalu besar, rasa makanan yang tidak terlalu enak serta kenyang dan malas makan. ${ }^{21}$

Seluruh diet yang diberikan untuk pasien rawat inap di Rumah Sakit Holistic diolah menggunakan sedikit garam namun kaya akan bumbu dan rempah-rempah alami lain yang dapat menyempurnakan rasa masakan. Hal ini merupakan langkah pengolahan diet pasien yang dilakukan oleh Instalasi Nutrisi Rumah Sakit Holistic dalam rangka meningkatkan pemenuhan asupan diet pasien selama menjalani rawat inap di rumah sakit. Namun pada kenyataannya, di awal pasien masuk rumah sakit, masih dijumpai sisa makanan yang tinggi, terutama untuk makanan pokok (nasi putih). Dengan kata lain, pengolahan diet khusus untuk pasien rumah sakit menggunakan rempah dan bumbu alami belum mampu meningkatkan keinginan dan selera makan pasien terhadap diet yang disajikan. Hal ini sejalan dengan hasil penelitian yang dilakukan tahun 2014 di Rumah Sakit Umum Florianopolis-Santa Catarina, Brazil. Penelitian tersebut menyatakan bahwa penambahan bumbu dan rempah-rempah serta modifikasi teknik pengolahan dan persiapan pada diet rendah natrium tidak mampu meningkatkan asupan makanan pasien rawat inap. ${ }^{22}$ Hasil penelitian lainnya juga menyatakan bahwa diet rumah sakit yang terkadang diberikan dalam bentuk lunak dan rendah garam juga dapat menurunkan minat pasien untuk mengonsumsi makanan tersebut. ${ }^{18}$

Rumah Sakit Holistic memiliki waktu pemberian makan dan komposisi menu makanan yang berbeda dengan rumah sakit pada umumnya. Diet diberikan kepada pasien sebanyak 6 kali waktu makan, yaitu sarapan, makan pukul 09.00, makan siang, makan pukul 16.00, makan malam, dan makan tambahan. Berbeda dengan rumah sakit pada umumnya, di Rumah Sakit Holistic, nasi putih sebagai sumber makanan pokok hanya diberikan pada menu makan siang saja, sedangkan pada jam makan lainnya pasien memperoleh sumber makanan pokok dari selain nasi. Hal ini merupakan bentuk strategi penyelenggaraan makanan Rumah Sakit Holistic dalam rangka memenuhi kebutuhan asupan makanan yang disesuaikan dengan kondisi patologis dan daya terima pasien. Hal ini sejalan dengan literatur yang menyebutkan bahwa makanan yang disajikan harus sesuai dengan jumlah atau porsi yang ditentukan. Besar atau kecil porsi makanan menjadi sangat penting terutama pada penyelenggaraan makanan bagi orang sakit dimana makanan juga berperan dalam memberikan terapi. ${ }^{23}$

Dengan kata lain, semakin kecil porsi makanan yang disajikan maka sisa makanan akan semakin sedikit begitu pula sebaliknya. Hasil penelitian ini sejalan dengan penelitian yang dilakukan pada tahun 2012 pada pasien kelas 3 Seruni di Rumah Sakit Puri Cinere Depok. Pasien yang memiliki asumsi terhadap ketidaksesuaian porsi makanan yang disajikan akan menyisakan makanan 4,6 kali lebih banyak dibandingkan pasien yang mengasumsikan porsi makanannya sudah sesuai. Hal ini karena beberapa pasien beranggapan bahwa porsi makanan yang disajikan terlalu banyak sehingga pasien sulit 
untuk menghabiskan makanan tersebut dalam satu kali waktu makan. ${ }^{24}$ Hasil penelitian yang berbeda ditunjukkan pada penelitian yang dilakukan di RS Haji Jakarta pada tahun 2011, yang menyatakan bahwa keadaan psikis, kebiasaan makan, porsi makan dan penyajian makanan, serta rasa makanan yang meliputi bumbu, konsistensi, dan keempukan makanan tidak berhubungan dengan terjadinya sisa makanan di Rumah Sakit Haji, Jakarta. ${ }^{25}$

Penelitian ini memiliki beberapa keterbatasan. Sulitnya mendapatkan subyek penelitian yang sesuai dengan kriteria inklusi dan eksklusi penelitian menyebabkan kecilnya jumlah sampel penelitian sehingga penelitian dilakukan tanpa adanya kelompok pembanding (kontrol) dan analisis data hanya dapat dilakukan melalui uji non-parametrik. Variabel yang diteliti tidak banyak sehingga analisis data hanya mampu dilakukan secara bivariat.

\section{SIMPULAN DAN SARAN}

\section{Simpulan}

Perbedaan usia, jenis kelamin dan jenis diet tidak berhubungan dengan sisa makanan (nasi puth) subyek penelitian yang sudah mengalami penurunan porsi diet. Perubahan porsi nasi putih dari porsi sedang menjadi kecil dapat menurunkan persentase sisa makanan. Perubahan porsi nasi putih (porsi sedang menjadi kecil) berhubungan dengan persentase sisa makanan subyek penelitian. Pengurangan porsi makanan yang disajikan mampu menurunkan sisa makanan.

\section{Saran}

Penelitian yang akan datang hendaknya dapat mengkaji lebih banyak variabel sehingga analisis multivariat dapat dilakukan, selain itu penelitian sebaiknya dilaksanakan di dua atau lebih lokasi yang berbeda, yaitu di Rumah Sakit Holistic dan rumah sakit lainnya untuk mendapatkan lebih banyak subjek penelitian dan dapat menggunakan kelompok pembanding (kontrol).

\section{UCAPAN TERIMA KASIH}

Ucapan terima kasih penulis sampaikan kepada Direktur Rumah Sakit Holistic, Purwakarta yang telah memberikan ijin penelitian sehingga penelitian ini dapat terselenggara. Ucapan terima kasih juga disampaikan kepada Kepala Instalasi Departemen Nutrisi dan Departemen Rekam Medik yang telah membantu dalam proses pelaksanaan penelitian serta kepada para pasien rawat inap yang telah bersedia menjadi responden dan berpartisipasi dalam penelitian ini.

\section{RUJUKAN}

1. Indonesia, Kementerian Kesehatan. Pedoman Pelayanan Gizi Rumah Sakit (PGRS). Jakarta: Kementerian Kesehatan RI, 2013.

2. Indonesia, Direktorat Bina Pelayanan Medik Dasar Direktorat Jenderal Bina Pelayanan Medik Departemen Kesehatan. Pedoman Penyelenggaraan Makanan Rumah Sakit. Jakarta: Direktorat Jenderal Bina Pelayanan Medik, 2007.

3. Almatsier S, Jus'at I, Akmal N. Persepsi pasien terhadap makanan di rumah sakit: Survei pada 10 rumah sakit di Jakarta. Gizi Indon. 1992; 17(2): 87-96.

4. Semedi P, Kartasurya MI, Hagnyonowati. Hubungan kepuasan pelayanan makanan rumah sakit dan asupan makanan dengan perubahan status gizi pasien: Studi di RSUD Sunan Kalijaga, Kabupaten Demak. Jurnal Gizi Indonesia 2013; 2(1): 32-41.

5. Williams $P$, Walton K. Plate waste in hospitals and strategies for change. eSPEN, the European e-Journal of Clinical Nutrition and Metabolism. 2011; 6(6): e235-e241.

6. Fadilah O. Gambaran sisa makanan, kontribusi zat gizi dan biaya makan pasien rawat inap di RSUD Salatiga. Skripsi. Surakarta: Program Studi S1 Gizi Fakultas IImu Kesehatan Universitas Muhammadiyah Surakarta, 2013 [cited 2016 Apr 30]. Available from:

http://eprints.ums.ac.id/27075/9/

\section{NASKAH PUBLIKASI.pdf.}

7. Puruhita N, Hagnyonowati, Adianto $S$, Murbawani EA, Ardiaria M. Gambaran sisa makanan dan mutu makanan yang disediakan Instalasi Gizi Rumah Sakit Umum Pusat Dr. Kariadi Semarang. JNH 2014; 2(3): 1-14.

8. Díaz AV; García AC. Evaluation of factors affecting plate waste of inpatients in 
different healthcare settings. Nutr Hosp. 2013; 28(2): 419-427.

DOI:10.3305/nh.2013.28.2.6262.

9. Sastroasmoro S, Ismael S. Dasar-Dasar Metodologi Penelitian Klinis. Edisi Ke-4. Jakarta: Sagung Seto, 2011.

10. Saryono. Metodologi Penelitian Kesehatan: Penuntun Praktis bagi Pemula. Yogyakarta: Mitra Cendikia Press, 2011.

11. Komalawati $D$ et al. Pengaruh lama rawat inap terhadap sisa makanan pasien anak di Rumah Sakit Umum Dr. Soeradji Tirtonegoro, Klaten. Nutrisia. 2005; 6(1).

12. Uyanto SS. Pedoman Analisis Data dengan SPSS. Edisi ke-3. Yogyakarta: Graha IImu, 2009.

13. Djamaluddin M, Endy PP, Ira P. Analisis zat gizi dan biaya sisa makanan pada pasien dengan makanan biasa di RS Dr. Sardjito, Yogyakarta. Jurnal Gizi Klinik Indonesia 2005; 1(3): 108-12.

14. Zakiah L, Saimy I, Maimunah AH. Plate waste among hospital inpatients. Malaysian Journal of Public Health Medicine 2005; 5(2): 19-24.

15. Wirasamadi NLP, Tresna AK, Weta IW. Analisis sisa makanan pasien rawat inap di RSUP Sanglah Denpasar Provinsi Bali. Public Health and Preventive Medicine Archive 2015; 3(1): 88-95.

16. Dillak SR, Setyowati, Fatimah F. Sisa makanan menurut karakteristik pasien hipertensi di RSUD Sleman, Yogyakarta. Jurnal Nutrisia. 2013; 15(2).

17. Freedman MR, Brochado C. Reducing portion size reduces food intake and plate waste. Obesity. 2010; 18(9): 1864-1866. DOI:10.1038/oby.2009.480.

18. Thibault R, Chikhi M, Clerc A, Darmon P, Chopard P, Genton L, et al. Assessment of food intake in hospitalised patients: A 10year comparative study of a prospective hospital survey. Clin Nutr. 2011; 30(3): 289-96.

DOI: 10.1016/j.clnu.2010.10.002.

19. Vartanian LR, Herman CP, Wansink B. Are we aware of the external factors that influence our food intake? Health Psychol. 2008; 27(5): 533-8. DOI: 10.1037/02786133.27.5.533.
20. Keller H, Allard J, Vesnaver E, Laporte M, Gramlich L, Bernier $P$, et al. Barriers to food intake in acute care hospitals: a report of the Canadian Malnutrition Task Force. J Hum Nutr Diet. 2015; 28(6): 54657. DOI: 10.1111/jhn.12314.

21. Anwar I, Herianandita E, Ruslita I. Evaluasi sistem penyelenggaraan makanan lunak dan analisis sisa makanan lunak di beberapa rumah sakit di DKI Jakarta, tahun 2011. Gizi Indon. 2012; 35(2): 97-108.

22. Alencar MLA, de Sousa AA, Trindade EBSM. Do spices and condiments increase food intake of patients with low sodium diet? Demetra 2014; 9(3): 795809. DOI: 10.12957/demetra.2014.11224.

23. Dewi LS. Faktor-faktor yang berhubungan dengan sisa makanan pada pasien rawat inap di Rumah Sakit Djatiroto Lumajang. Skripsi. Jember: Bagian Gizi Kesehatan Masyarakat Fakultas Kesehatan Masyarakat Universitas Jember [online]. 2015 [cited 2016 Apr 30]. Available from: http://repository.unej.ac.id/handle/1234567 $89 / 65852$.

24. Lumbantoruan DBS. Hubungan penampilan makanan dengan faktor lainnya dengan sisa makanan biasa pasien kelas 3 Seruni RS Puri Cinere Depok. Skripsi. Depok: Program Studi Sarjana Gizi Fakultas Kesehatan Masyarakat Universitas Indonesia [online]. 2012 [cited 2016 Apr 30]. Available from: http://lib.ui.ac.id/file?file=digital/20320509S-PDF-Dian\%20Berdhika\%20Sari\%20 Lumbantoruan.pdf.

25. Aula LE. Faktor-faktor yang berhubungan dengan terjadinya sisa makanan pada pasien rawat inap di Rumah Sakit Haji Jakarta tahun 2011. Skripsi. Jakarta: Program Studi Kesehatan Masyarakat Fakultas Kedokteran dan IImu Kesehatan Universitas Islam Negeri Syarif Hidayatullah Jakarta [online]. 2011 [cited 2016 Apr 30]. Available from: http://repository.uinjkt.ac.id/dspace/bitstrea $\mathrm{m} /$ 123456789/1812/1/

LIZA\%20ELLIZABET\%20AULAFKIK.PDF. 